\title{
Characterization of a Fine-Grained Interstratification of Turbostratic Talc and Saponite
}

\author{
Annett Steudel ${ }^{1, *}$, Frank Friedrich ${ }^{2}$, Rainer Schuhmann ${ }^{1}$, Friedrich Ruf ${ }^{3}$, Ulrich Sohling ${ }^{3,4}$ \\ and Katja Emmerich ${ }^{1}$ \\ 1 Competence Center for Material Moisture (CMM), Karlsruhe Institute of Technology, \\ Hermann-von-Helmholtz-Platz 1, D-76344 Eggenstein-Leopoldshafen, Germany; \\ rainer.schuhmann@kit.edu (R.S.); katja.emmerich@kit.edu (K.E.) \\ 2 Chair of Foundation Engineering, Soil- and Rock Mechanics, Ruhr-University Bochum, \\ Universitätsstraße 150, 44780 Bochum, Germany; fwfriedrich@googlemail.com \\ 3 Clariant Produkte (Deutschland) $\mathrm{GmbH}$, BU Functional Minerals, BL Adsorbents, \\ Ostenrieder Str. 15, 85368 Moosburg, Germany; friedrich.ruf@clariant.com (F.R.); \\ ulrich.sohling@clariant.com (U.S.) \\ 4 Clariant Produkte (Deutschland) $\mathrm{GmbH}$, Competence Center Colorants \& Functional Chemicals, \\ Group Technology \& Innovation, Industriepark Höchst, Gebäude G 860 (CIC), 65926 Frankfurt, Germany \\ * Correspondence: annett.steudel@kit.edu; Tel.: +49-721-608-26805; Fax: +49-721-608-23478
}

Academic Editors: Annalisa Martucci and Huifang Xu

Received: 8 November 2016; Accepted: 23 December 2016; Published: 5 January 2017

\begin{abstract}
Interstratifications of talc and trioctahedral smectites from different provenances are used as indicators for geological environments and for geotechnical and technical applications. However, comprehensive layer characterization of these interstratifications is rare. Sample EX M 1694, a clay with red-beige appearance from the Madrid basin was studied by X-ray diffraction analysis, X-ray fluorescence analysis, Fourier transformation infrared spectroscopy, simultaneous thermal analysis, gas adsorption measurements, cation exchange capacity, and environmental scanning electron microscopy. More than $95 \%$ of particles in EX M 1964 belong to the clay fraction $<2 \mu \mathrm{m}$. It contains $75 \%$ interstratification of $30 \%$ turbostratic talc, and $70 \%$ saponite type III and $25 \%$ turbostratic talc. The turbostratic talc(0.3)/saponite interstratification is characterized by a low number of layers per stack (3), small lateral dimension of layers $(60-80 \mathrm{~nm})$ and, accordingly, a high specific surface area $\left(283 \mathrm{~m}^{2} / \mathrm{g}\right)$ with nearly equal surface area of micro- and mesopores. Thus, the studied material can be used as mined for adsorption, in contrast to acid-treated clays that produce hazardous waste during production. Low particle size of the interstratification drastically reduced thermal stability and dehydroxylation was superimposed by recrystallization of high temperature phases already at $816^{\circ} \mathrm{C}$, which is low for trioctahedral 2:1 layer minerals.
\end{abstract}

Keywords: talc; kerolite; saponite; stevensite; mixed layer; modelling of one-dimensional X-ray pattern; simultaneous thermal analysis

\section{Introduction}

Interstratifications of talc and trioctahedral smectite layers are formed as an abundant mineral in lake and/or spring deposits of Miocene to Pleistocene age and in serpentinized rocks formed by a transformation of ultramafic rocks at low temperature.

Turbostratic talc/trioctahedral smectite interstratifications occur, for example, in the Province Parma (Italy) [1], in the Armagosa Desert (Nevada) [2], and in the Madrid basin (Spain) [3-6], which is the most extensive studied locality. The interstratifications are often very fine-grained and analysis and description of the interstratification is still difficult. Turbostratic talc has the same chemical composition as talc, but displays a fully turbostratic structure [7-9] and was called kerolite 
or disordered talc in the past. The term kerolite was discredited by the International Mineralogical Association (IMA)/Commission on new minerals, nomenclature, and classification (CNMNC) in 2008 [10,11], but is still in use in recent literature e.g., Guggenheim [12], because turbostratic talc is regarded as a variety of talc. Nevertheless, in this paper turbostratic talc will be used according to IMA regulations. Stacks of turbostratic talc contain less than $4-5$ layers and show broad basal reflections with an increased basal spacing of about $0.96 \pm 0.005 \mathrm{~nm}$ compared to talc $(0.936 \mathrm{~nm}$; [13]). In the talc structure the oxygen atoms of adjacent layers are partially packed together, thereby, the layers are close together. If the distance between the oxygen atoms changed with rotation of layers, the layers would be $0.027 \mathrm{~nm}$ further apart. Thus, the sum of the basal reflection of talc $0.936 \mathrm{~nm}$ plus $0.027-0.029 \mathrm{~nm}$ due to disorder, gives $0.963-0.965 \mathrm{~nm}$, which corresponds with the observed spacing of turbostratic talc [7]. Specific surface area, determined by gas adsorption methods, is about $200 \mathrm{~m}^{2} / \mathrm{g}$, which also indicates small particle size. Compared to talc, turbostratic talc is supposed to hold additional water in the structure, which is probably mainly surface-held water [7].

One challenge is to identify the character of the trioctahedral smectite (saponite vs. stevensite) in the interstratifications. Stevensite and saponite are hydrous magnesium silicates belonging to the smectite group [14] with a 060 reflection at $0.152 \mathrm{~nm}$. Stevensite differs from saponite by a complete absence of trivalent cations ( $\mathrm{Al}$ and $\mathrm{Fe}(\mathrm{III})$ ). The resulting layer charge of stevensite is caused by a deficiency of octahedral cations. The layer charge of stevensite is at the lower limit (near 0.2 per formula unit, p.f.u.) for known layer charges of smectite $[15,16]$. In contrast, saponite shows a larger variability in chemical composition. Saponites are characterized by a higher layer charge p.f.u. (0.3-0.5) that is more common for smectites. Saponite type I is characterized by tetrahedral substitutions without octahedral substitutions [16,17], whereas saponite type II is characterized by an additional positive octahedral charge [18]. Furthermore, saponites may be either iron-free or have octahedral iron, which results in saponite type III $[16,18]$. Type II saponites show a tendency of a small number of octahedral vacancies [15]. Examples of common formulae are:

Stevensite: $\mathrm{M}_{0.2}^{+}\left(\mathrm{Si}_{4}\right)\left(\mathrm{Mg}_{2.9}\right) \mathrm{O}_{10}(\mathrm{OH})_{2}$;

Saponite: type I; $\mathrm{M}_{0.3}^{+}\left(\mathrm{Si}_{3.7} \mathrm{Al}_{0.3}\right)\left(\mathrm{Mg}_{3}\right) \mathrm{O}_{10}(\mathrm{OH})_{2}$;

type II: $\mathrm{M}_{0.3}^{+}\left(\mathrm{Si}_{3.6} \mathrm{Al}_{0.4}\right)\left(\mathrm{Mg}_{2.9} \mathrm{Al}_{0.1}\right) \mathrm{O}_{10}(\mathrm{OH})_{2}$;

type III: $\mathrm{M}_{0.3}^{+}\left(\mathrm{Si}_{3.72} \mathrm{Al}_{0.28}\right)\left(\mathrm{Mg}_{2.51} \mathrm{Al}_{0.19} \mathrm{Fe}_{0.13}^{3+}\right) \mathrm{O}_{10}(\mathrm{OH})_{2}$.

From the different layer structure of saponite and stevensite, the distance of charge to the layer surface is obviously different, which will determine hydration and sorption properties significantly $[19,20]$.

The aim of the present study was the unambiguous characterization of a clay from the Madrid basin, which shows exceptional suitability as adsorbent material in biotechnology processes [21], and as adsorbent for mycotoxins [22]. In addition, pesticide removal from water has been demonstrated [23] for this clay. This clay can be also used to bind contaminants from the manufacture of paper [24]. Our study was initiated to better understand the structure-functionality relation of this material to potentially enhance its industrial use. The identification of smectite is important as saponite and stevensite vary in charge distribution influencing the absorption behavior of the material.

\section{Material}

Sample EX M 1694 (Clariant-internal distinct sample/clay quality, Clariant Produkte (Deutschland) $\mathrm{GmbH}$, Frankfurt, Germany), a clay with a red-beige appearance from the Madrid basin, Spain) was studied to identify its mineralogical and chemical characteristics, especially the mineralogy of the interstratification.

\section{Methods}

Most methods to characterize 2:1 layer silicates were described in detail by Wolters et al. [25] and Steudel et al. [26]. Hence, only a brief description is provided here supplemented by detailed 
description of new methods. The methods were applied to the raw material as received and to the clay fraction $(<2 \mu \mathrm{m}$; Na-exchanged), but the results here are focused primarily on the clay fraction.

\subsection{Sample Preparation and Size Fractionation}

The raw material $(500 \mathrm{~g}$ ) was divided by a rotating sample splitting device (rotary sample divider laborette 27, Fritsch, Idar-Oberstein, Germany) to obtain about $30 \mathrm{~g}$ of representative samples for mineralogical characterization. Chemical pre-treatments after Tributh and Lagaly [27] were applied to remove traces of carbonates, iron oxides, and organic matter [25]. Size fractionation was initiated to remove coarse crystallites of non-clay minerals and to enrich particles of $<2 \mu \mathrm{m}$. For size separation, the material was first suspended in deionized water $(800 \mathrm{~mL})$ by mixing in an ultrasonic bath $(30 \mathrm{~min}$, Merck Eurolab, Darmstdt, Germany) and shaken overnight. The homogenous suspension was transferred into a $5 \mathrm{~L}$ beaker by passing a $63 \mu \mathrm{m}$ sieve, which allowed separation of larger particles. The remaining suspension was diluted with deionised water to a solid content of about $1 \%$. The $<2 \mu \mathrm{m}$ fraction was obtained by repeated gravitational sedimentation. The large volume was flocculated with $\mathrm{NaCl}$ $(20 \times \mathrm{CEC}$, see below). Excess salt in the sediment was removed by dialysis (conductivity of surrounding deionized water $<5 \mu \mathrm{S} / \mathrm{cm}$ ). The dialysis tube (Nadir ${ }^{\circledR}$, Carl Roth $\mathrm{GmbH}$, Karlsruhe, Germany) consisted of cellulose hydrate with a width of $62.8 \mathrm{~mm}$ and a diameter of $40 \mathrm{~mm}$. The chloride-free clay fraction was dried at $60^{\circ} \mathrm{C}$, gently manually ground (agate mortar) and stored in closed sample containers.

\subsection{X-ray Diffraction (XRD) Analysis}

The XRD patterns of the powdered bulk material and the clay fraction $(<2 \mu \mathrm{m})$ were used for mineral identification and quantification. Mineral identification proceeded further by XRD patterns of oriented samples prepared from the clay fraction. Oriented samples were prepared by dispersing about $80 \mathrm{mg}$ of the Na-exchanged $<2 \mu \mathrm{m}$ fraction in $2 \mathrm{~mL}$ deionized water. Samples were dried under atmospheric conditions at room temperature. After analyzing, the air dried samples were solvated for $48 \mathrm{~h}$ with ethylene glycol (EG) in a desiccator at $60^{\circ} \mathrm{C}$.

Measurements were performed with a Siemens D5000 (Bruker AXS GmbH, Karlsruhe, Germany) instrument equipped with a graphite diffracted-beam monochromator $(\mathrm{CuK} \alpha, 40 \mathrm{kV}, 40 \mathrm{~mA}$, from $2^{\circ}-45^{\circ} 2 \theta$, step width $0.02^{\circ} 2 \theta, 3 \mathrm{~s} / \mathrm{step}$, divergence and antiscatter slit $0.6 \mathrm{~mm}$, detector slit $1.0 \mathrm{~mm}$ ). The mineral names were abbreviated according to Whitney and Evans [28].

\subsection{Modeling of the One-Dimensional X-ray Pattern}

"NEWMOD" was used to model one-dimensional X-ray pattern of different interstratifications to compare them with a measured XRD pattern of EG-solvated oriented specimen from our sample [29]. The EG-treated pattern was used to model the XRD data because the EG fixes the layer-to-layer space. In the air-dried state the basal spacing is sensitive to ambient humidity and the type of interlayer cations. Thus, it is difficult to determine the hydration state of the sample. Air-dried sample data are included here as a baseline to observe changes by EG solvation. A talc/smectite interstratification was selected for modeling. According to Moore and Reynolds [18], talc can be simulated by a trioctahedral mica model with zero values for $\mathrm{K}$ and Fe and by changing d(001) from 1.0 to $0.933 \mathrm{~nm}$. A d(001) of $0.96 \mathrm{~nm}$ for turbostratic talc was applied during the modeling. For the swelling layers the following structure was selected: trioctahedral smectite-2Gly with a d(001) of $1.69 \mathrm{~nm}$.

\subsection{Infrared Spectroscopy -Attenuated Total Reflection Spectroscopy (ATR)}

A Bruker IFS 55 EQUINOX spectrometer, equipped with a DTGS (deuterated triglycine sulphate) (Bruker Optik GmbH, Ettlingen, Germany) detector was employed to obtain IR-spectra. 64 scans in the $4000-400 \mathrm{~cm}^{-1}$ spectral range were recorded with a scanner velocity of $5 \mathrm{kHz}$ and a resolution of $4 \mathrm{~cm}^{-1}$. For the ATR measurements, a MIRacle single reflection diamond ATR cell (PIKE Technologies, Madison, WI, USA) was used. Sample preparation was simple: a small amount of powder was pressed on the diamond surface by a stainless steel-tipped anvil. 
Band component analysis was undertaken using the Jandel Peakfit software package, (Version 4.12, Jandel Scientific, SeaSolve Software, Framingham, MA, USA), which enables the type of fitting function to be selected and allows specific parameters to be fixed or varied accordingly. The band fitting was done over a region from 1300 to $830 \mathrm{~cm}^{-1}$ using a Voigt function. A linear two-point background was chosen and fitting runs were repeated until reproducible results were obtained with a squared correlation parameter $\mathrm{R}^{2}$ better than 0.998 .

\subsection{X-ray Fluorescence (XRF) Analysis}

The chemical composition of the raw material and of the clay fraction $(<2 \mu \mathrm{m}$; Na-exchanged $)$ was determined by XRF using molten pellets with lithium tetraborate (mixing ratio 1:7). XRF analyses were performed on a Philips MagiXPRO spectrometer (PANalytical B.V., Almelo, The Netherlands, Company of Spectris plc., Egham, UK) equipped with a rhodium X-ray tube operated at $3.2 \mathrm{KW}$. The loss-on-ignition was determined prior to XRF by heating the samples at $1000{ }^{\circ} \mathrm{C}(2 \mathrm{~h})$.

\subsection{Simultaneous Thermal Analysis (STA)}

The measurements were performed on a STA 449 C Jupiter (NETZSCH-Gerätebau GmbH, Selb, Germany) equipped with a thermogravimetric/differential scanning calorimetry (TG/DSC) sample holder. The STA is connected to a quadrupole mass spectrometer $403 \mathrm{C}$ Aëolos (InProcess Instruments (IPI)/NETZSCH-Gerätebau GmbH, Selb, Germany) to detect the evolved gases from the sample during heating. All samples were allowed to equilibrate at a relative humidity (r.h.) of $53 \%$ in a desiccator above a saturated $\mathrm{Mg}\left(\mathrm{NO}_{3}\right)_{2}$ solution for at least $48 \mathrm{~h}$. Conventional $\mathrm{Pt} / \mathrm{Rh}$ crucibles (diameter $5 \mathrm{~mm}$ and height $5 \mathrm{~mm}$ ) with a loosely-fitting perforated lid were filled with $80 \mathrm{mg}$ of sample material. The measurements in the temperature range between 35 and $1100{ }^{\circ} \mathrm{C}$ with a heating rate of $10 \mathrm{~K} / \mathrm{min}$ and an isothermal segment at $35^{\circ} \mathrm{C}$ for $10 \mathrm{~min}$ were obtained under flowing synthetic air (SynA, $50 \mathrm{~mL} / \mathrm{min})$ mixed with nitrogen $(20 \mathrm{~mL} / \mathrm{min})$ from the protective gas flow. The STA is connected to a pulse box (PulseTA, NETZSCH-Gerätebau GmbH, Selb, Germany) to inject a fixed volume of $\mathrm{CO}_{2}(1 \mathrm{~mL})$ in the flowing gas. Recording of the evolved $\mathrm{CO}_{2}$ from sample and injected $\mathrm{CO}_{2}$ allows the quantification of the evolved $\mathrm{CO}_{2}$ e.g., from the oxidation of organic matter or from the decomposition of carbonates, [30]. Therefore, a $40 \mathrm{~min}$ isothermal segment is performed at the end of the measurement to inject $\mathrm{CO}_{2}$ three times.

\subsection{Cation Exchange Capacity (CEC) and Exchangeable Cations}

To determine the CEC, the exchangeable cations were replaced by copper triethylenetetramine (Cu-trien) [31]. Prior to this exchange, the samples were also stored at 53\% r.h. for at least $24 \mathrm{~h}$. Fifty milligrams of the samples were dispersed in $5 \mathrm{~mL} 0.01 \mathrm{M} \mathrm{Cu}$-complex solution. Ten milliliters of deionized water were added and the dispersions were shaken for $3 \mathrm{~h}$. The dispersions were centrifuged once at a minimum of $3500 \mathrm{rpm}$ for $10 \mathrm{~min}$; afterwards, the clear blue supernatants $(1 \mathrm{~mL})$ were transferred into cuvettes $(1.5 \mathrm{~mL}$; semi-micro; disposable, Plastibrand, Brand GmbH \& Co. KG, Wertheim, Germany). The depletion of the Cu-trien cations in the sample solutions was determined by photometry at $580 \mathrm{~nm}$ using a calibration series with different concentrations of $\mathrm{Cu}$-trien. The CEC was related to the dry weight of the completely dehydrated material calculated with respect to water content determined by simultaneous thermal analysis (STA).

Exchangeable cations $\left(\mathrm{Na}^{+}, \mathrm{Ca}^{2+}, \mathrm{K}^{+}, \mathrm{Mg}^{2+}\right)$ were determined with an optical emission spectrometer, where inductively-coupled plasma is used for excitation of the cations (ICP-OES; Jobin Yvon JY 38 S, HORIBA Europe GmbH, Oberursel, Germany). For the analysis, $5 \mathrm{~mL}$ of the supernatant solution from CEC determination were transferred with a pipette (Eppendorf $\mathrm{GmbH}$, Wesseling-Berzdorf, Germany) into a vial and diluted with deionized water in volume ratios of 1:1, $1: 2$, or 1:4 depending on the expected ion concentration from the CEC results. Ten to $20 \mu \mathrm{L}$ of $\mathrm{HNO}_{3}$ (65\% supra pure) were added to decompose the $\mathrm{Cu}$-trien complex and to stabilize the solutions. 


\subsection{Environmental Scanning Electron Microscope (ESEM)}

Particle morphologies were examined by a Philips XL 30 FEG environmental scanning electron microscope (ESEM) (FEI Europe, Eindhoven, The Netherlands). Small amounts of sample powder were glued on aluminum SEM-holders using conductive tapes (Leit-C, Plano GmbH, Wetzlar, Germany). To improve the image quality, the samples were sputtered with a thin conductive layer $(5 \mathrm{~nm} \mathrm{Au} / \mathrm{Pd} 80 / 20)$ and were investigated in low-vac mode at a chamber pressure of 1 Torr (130 Pa) using an acceleration voltage of $15 \mathrm{kV}$.

\subsection{Specific Surface Area $\left(A_{S}\right)$}

$\mathrm{N}_{2}$ adsorption/desorption isotherms were recorded using either a Quantachrome Autosorb-1MP (Quantachrome Instruments, Boynton Beach, FL, USA) or an ASAP2010 (Micromeritics). To remove gaseous surface contaminants from the sample surfaces, the samples were held $24 \mathrm{~h}$ under vacuum at $95{ }^{\circ} \mathrm{C}$ prior to the gas sorption cycle. Specific surface area $\left(\mathrm{A}_{S}\right)$ was calculated by applying BET theory [32]. Six to 11 adsorption points in the range of $\mathrm{p} / \mathrm{p}_{0}$ from 0.01 to 0.2 were used for BET evaluation. The density functional theory (DFT) was applied to calculate micro- $(<2 \mathrm{~nm})$, meso- $(2-50 \mathrm{~nm})$ and macropore $\left(>50 \mathrm{~nm}\right.$ ) volumes and areas (for definition of pore ranges see [33]) from the $\mathrm{N}_{2}$ adsorption isotherm. For this purpose, the DFT kernel provided by the Quantachrome evaluation program was used. The DFT kernel is based on $\mathrm{N}_{2}$ adsorbed at $77 \mathrm{~K}$ on silica surfaces with cylindrical pores and the non-local density functional theory (NLDFT) adsorption branch model [34]. The As was used to determine the range of square length (L) of the particles and layer (n) per stack [35-37].

\section{Results and Discussion}

\subsection{Mineralogy}

A broad diffraction peak below $10^{\circ}(2 \theta)$ in the powder pattern of both the bulk sample (data not shown) and the clay fraction (Figure 1) revealed small coherent scattering domains. A 060 reflection at $0.152 \mathrm{~nm}$ revealed the existence of mainly trioctahedral clay minerals. No 060 reflection for dioctahedral clay minerals was observable). A small diffraction peak at the low angle side of the $0.319 \mathrm{~nm}$ reflection indicated traces of quartz in the bulk sample. Further impurities were calcite and gypsum, which could be proved by a peak in the mass spectrometer (MS) curve of evolved $\mathrm{CO}_{2}(\mathrm{~m} / z=44)$ and $\mathrm{SO}_{2}$ $(m / z=64)$ during STA. The amount of calcite and gypsum was under the detection limit of XRD. The amount of the interstratification in the raw material and in the clay fraction was $>97 \%$ and $>99 \%$, respectively. The powder pattern of the clay fraction showed typical hk reflections of the trioctahedral clay minerals at $0.455 \mathrm{~nm}$ and $0.257 \mathrm{~nm}$ (Figure 1). An additional reflection at $0.319 \mathrm{~nm}$ was observable, which was identified as the $005 / 003$ reflection of the interstratification [9].

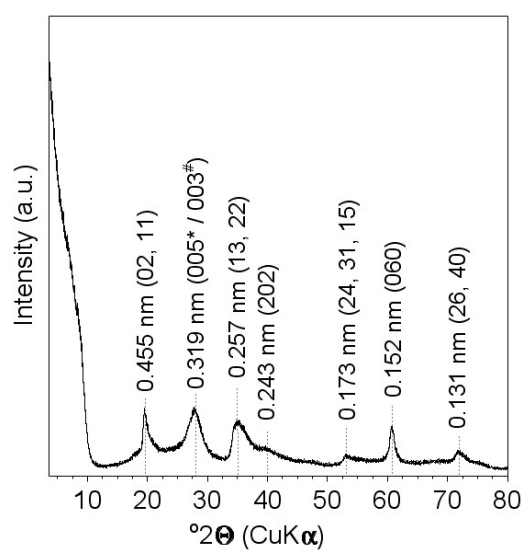

Figure 1. Powder pattern of the clay fraction $<2 \mu \mathrm{m}$. In addition to the hkl reflections one 001 reflection of the interstratification contribution from $\left({ }^{*}\right)$ saponite and $\left(^{\#}\right)$ turbostratic talc could be detected. 
In the air-dried oriented pattern of the clay fraction (Figure 2) the first basal reflection is very broad and has a small shoulder at higher $2 \theta$ values, typical for interstratifications. Small particle sizes and turbostratic stacking produced line broadening in the X-ray pattern. After treatment with ethylene glycol, the broad diffraction peak splits in two diffraction peaks, due to the swelling of the smectite layers in the interstratification (Figure 2). Both the Na-exchanged and Ca-exchanged material showed after EG solvation the same expansion behavior (data not shown).

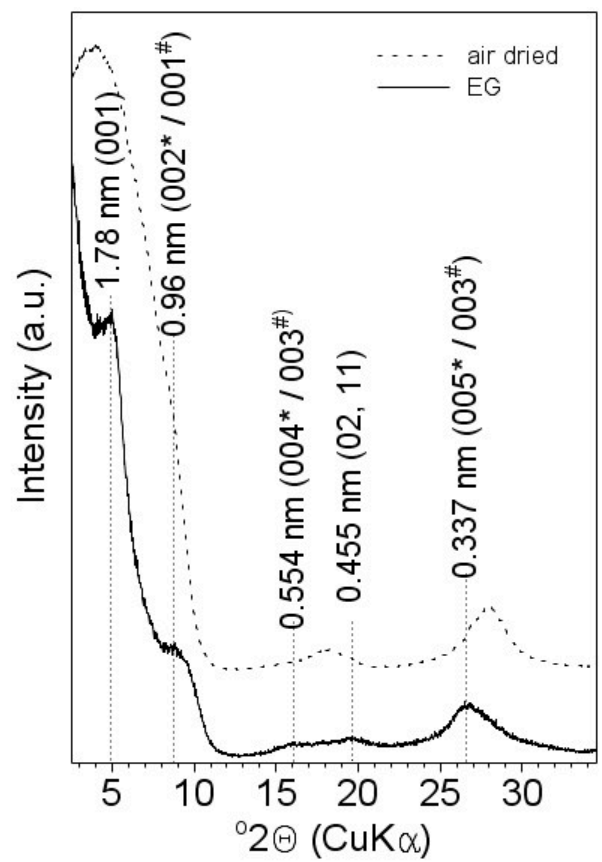

Figure 2. XRD patterns of the oriented clay fraction sample $<2 \mu \mathrm{m}$. Non-rational basal reflections in the EG treated pattern with contributions from saponite $\left(^{*}\right)$ and turbostratic talc $\left(^{\#}\right)$ are indicated.

The FTIR spectra of the clay fraction of sample EX M 1694 were dominated by only a few features (Figure 3a). In detail, these features are a small band at $3675 \mathrm{~cm}^{-1}$, which is at the same position as a talc-like $\mathrm{Mg}_{3} \mathrm{OH}$ stretching vibration. The substitution of $\mathrm{Al}$ for $\mathrm{Si}$, which transforms talc to $\mathrm{Mg}$-rich smectite, leads to a remarkable broadening and to a slight displacement $\left(5-10 \mathrm{~cm}^{-1}\right)$ of absorption bands of talc in the region below $1200 \mathrm{~cm}^{-1}$ (Figure 3a), which is in good agreement to Russel and Fraser [38]. The very broad band between 3650 and $3000 \mathrm{~cm}^{-1}$ shows three maxima at 3621,3420, and $3220 \mathrm{~cm}^{-1}$. They can all be assigned to stretching vibrations of adsorbed water molecules on the clay surfaces [38]. The fingerprint region is dominated by a strong band at around $990 \mathrm{~cm}^{-1}$ (Figure 3a), having a number of shoulders on both sides. A spectrum deconvolution reveals four bands at 1092, 1057,1015 , and $973 \mathrm{~cm}^{-1}$ (Figure $3 \mathrm{~b}$ ), which can all be attributed to Si-O stretching modes, a common feature in clay mineral spectra [39].

The peak deconvolution reveals two more weak bands at 915 and $880 \mathrm{~cm}^{-1}$. Both band positions are not reported for trioctahedral clay minerals, but are assigned to $\mathrm{Al}-\mathrm{OH}-\mathrm{Al}$ and $\mathrm{Al}-\mathrm{OH}-\mathrm{Fe}$ bending vibrations by Gates [40]. In addition, Cuadros et al. [10] attributed a band around $790 \mathrm{~cm}^{-1}$ in a talc-smectite interstratification to Fe-Mg- $\square-\mathrm{OH}$ sites and a band around $800 \mathrm{~cm}^{-1}$ to Fe-Fe- $\square-\mathrm{OH}$ sites [41].

The sharp band at $665 \mathrm{~cm}^{-1}$ is assigned to a $\mathrm{Mg}_{2}-\mathrm{R}-\mathrm{OH}$ bending mode with $\mathrm{R}=\mathrm{Mg}$ for talc and $\mathrm{R}=\mathrm{Fe}, \mathrm{Al}$ for saponite. Its position is slightly lower than in talc $\left(670 \mathrm{~cm}^{-1}\right)$ but higher than in saponite $\left(655 \mathrm{~cm}^{-1}\right)$. This possibly occurs due to the interstratification of both types of layers and few substitutions in saponite layers.

The strong feature below $500 \mathrm{~cm}^{-1}$ seems to be a mixture of talc and saponite vibrations and is obviously not easy to assign. It has two maxima ( 440 and $\left.421 \mathrm{~cm}^{-1}\right)$ and a shoulder at $464 \mathrm{~cm}^{-1}$. 
This shoulder was assigned by Farmer [42] to a perpendicular $\mathrm{Mg}_{3}-\mathrm{OH}$ bending vibration, while other authors attributed all bands to bending vibrations of the Si-O tetrahedra [43] or to vibrations of $\mathrm{Si}-\mathrm{O}-\mathrm{Mg}\left(464,440 \mathrm{~cm}^{-1}\right)$ and Si-O units $\left(421 \mathrm{~cm}^{-1}\right)$ [44].

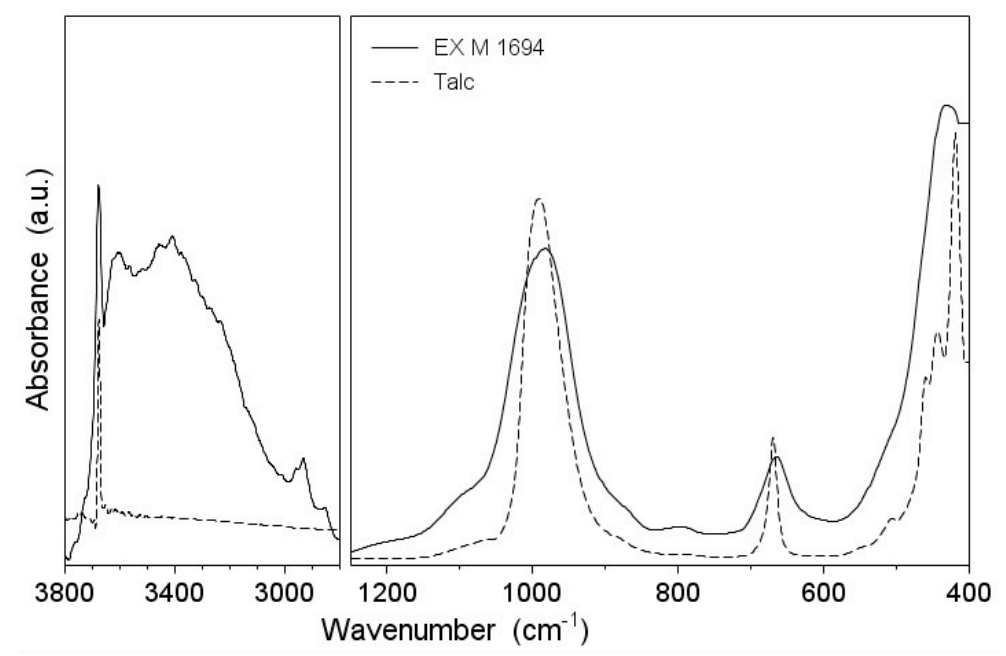

(a)

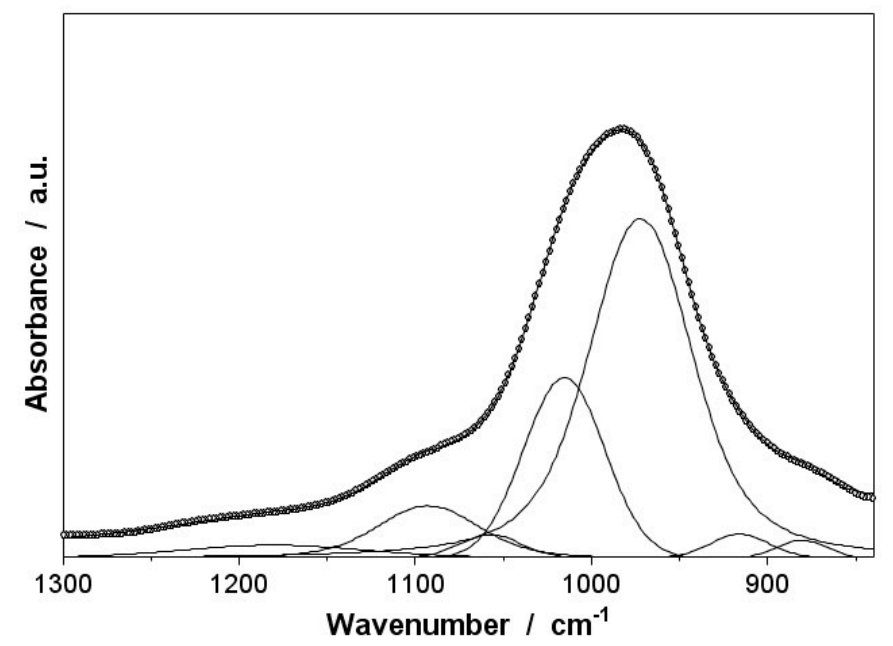

(b)

Figure 3. (a) Comparison of FTIR-ATR spectra of sample EX M 1694 and of talc; (b) Results of the spectrum deconvolution in the region between 830 and $1300 \mathrm{~cm}^{-1}$. The band positions are at 880,916 , $973,1015,1057,1092 \mathrm{~cm}^{-1}$.

The differential scanning calorimetric (DSC) curves (Figure 4) show one endothermic peak in the region below $200^{\circ} \mathrm{C}$, which is associated with a maximum $\left(130^{\circ} \mathrm{C}\right)$ in the mass spectrometer (MS) curve of $\mathrm{H}_{2} \mathrm{O}(\mathrm{m} / z=18)$, which reflects the release of adsorbed and interlayer water of a smectitic phase. Between $200{ }^{\circ} \mathrm{C}$ and $500{ }^{\circ} \mathrm{C}$, a broad exothermic reaction occurs, which can be associated with the oxidation of some surface attached organic matter due to released $\mathrm{H}_{2} \mathrm{O}$ and $\mathrm{CO}_{2}$. Two further reactions were observed at higher temperatures $\left(>500^{\circ} \mathrm{C}\right)$ in the DSC curve. The first reaction was endothermic, but the peak maximum could not be determined in the DSC curve because the reaction is superposed by an exothermic reaction. The reactions are associated with gas emissions in the $\mathrm{MS}$ curve of $\mathrm{H}_{2} \mathrm{O}$ $(m / z=18)$ and $\mathrm{CO}_{2}(m / z=44)$ and a mass loss of $4.1 \%$. The $\mathrm{H}_{2} \mathrm{O}$ release at $700{ }^{\circ} \mathrm{C}$ and above can be attributed to the dehydroxylation of trioctahedral clay minerals. Dehydroxylation (endothermal) occurs simultaneously with decomposition of clay minerals and recrystallization (exothermal) of high temperature phases. Thus, the maximum of the dehydroxylation peak $\left(816 \pm 1^{\circ} \mathrm{C}\right)$ could 
only be determined by DTG and from the MS curve of evolved $\mathrm{H}_{2} \mathrm{O}(m / z=18)$. The small $\mathrm{CO}_{2}$ release can be attributed to the decomposition of a carbonate, which also occurred simultaneously to the dehydroxylation of the clay mineral components. A small amount of carbonates $(<1 \%)$ were determined by PulseTA.
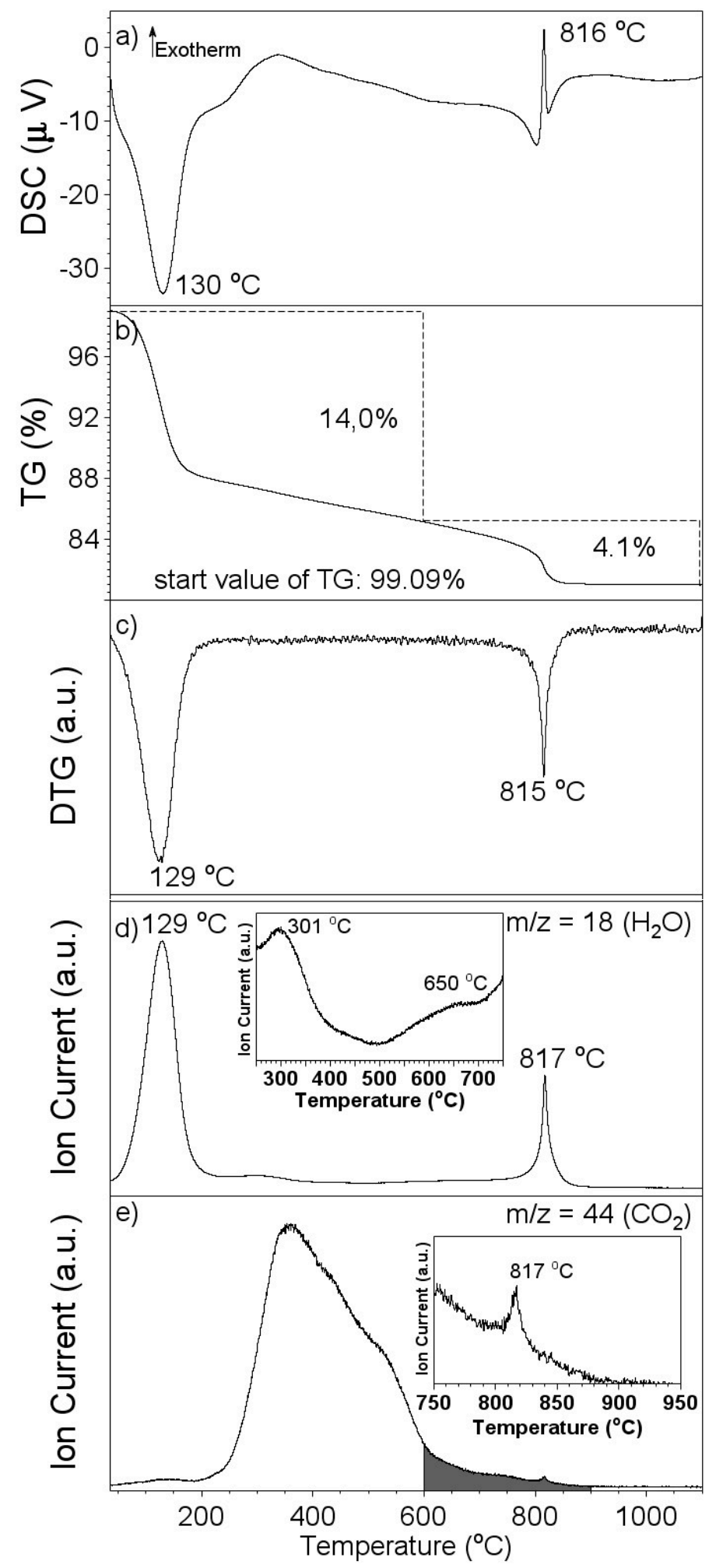

Figure 4. STA measurement of the clay fraction under SynA/ $\mathrm{N}_{2}$ : (a) DSC curve; (b) TG curve; (c) DTG curve; (d) MS curve of $\mathrm{H}_{2} \mathrm{O}$; and (e) MS curve of $\mathrm{CO}_{2}$. 
Chemical analysis showed that the raw material and the clay fraction contain $\mathrm{Si}$ and $\mathrm{Mg}$ as main elements, which is consistent with the existence of Mg-rich clay mineral components, which are trioctahedral. The amount of $\mathrm{Al}$ was below $2 \%$ and the amount of Fe was below 1\% (Table 1). The LOI of the raw material and for the clay fraction was $21.33 \mathrm{wt} \%$ and $18.08 \mathrm{wt} \%$, respectively. The nickel content of the both materials averaged $<10 \mathrm{ppm}$. The low Ni content is related to the composition of the parent rocks. The raw material has a $\mathrm{Ca}^{2+} / \mathrm{Mg}^{2+}$ ratio of about 1:2 in the interlayer.

Table 1. Chemical composition of raw material and clay fraction (normalized to ignited conditions).

\begin{tabular}{ccccccccc}
\hline EX M 1694 & $\mathbf{S i O}_{2}$ & $\mathbf{A l}_{\mathbf{2}} \mathbf{O}_{3}$ & $\mathbf{M g O}$ & $\mathbf{F e}_{2} \mathbf{O}_{3}$ & $\mathbf{N a}_{2} \mathbf{O}$ & $\mathbf{C a O}$ & $\mathbf{K}_{2} \mathbf{O}$ & Total \\
\hline Raw material (wt \%) & 62.76 & 1.76 & 33.56 & 0.61 & 0.04 & 0.86 & 0.41 & 100 \\
Clay fraction * (wt \%) & 63.82 & 1.84 & 32.20 & 0.55 & 1.36 & 0.04 & 0.18 & 100 \\
\hline
\end{tabular}

A comparison of ESEM images of the raw material and the clay fraction of EX M 1694 (Figure 5a,b) indicates, that the clay mineral particles formed small aggregates of about $4 \mu \mathrm{m}$ and show floccules of micro aggregates. These aggregates show the typical fluffy or cloud-like smectite-morphology (Figure 5b).
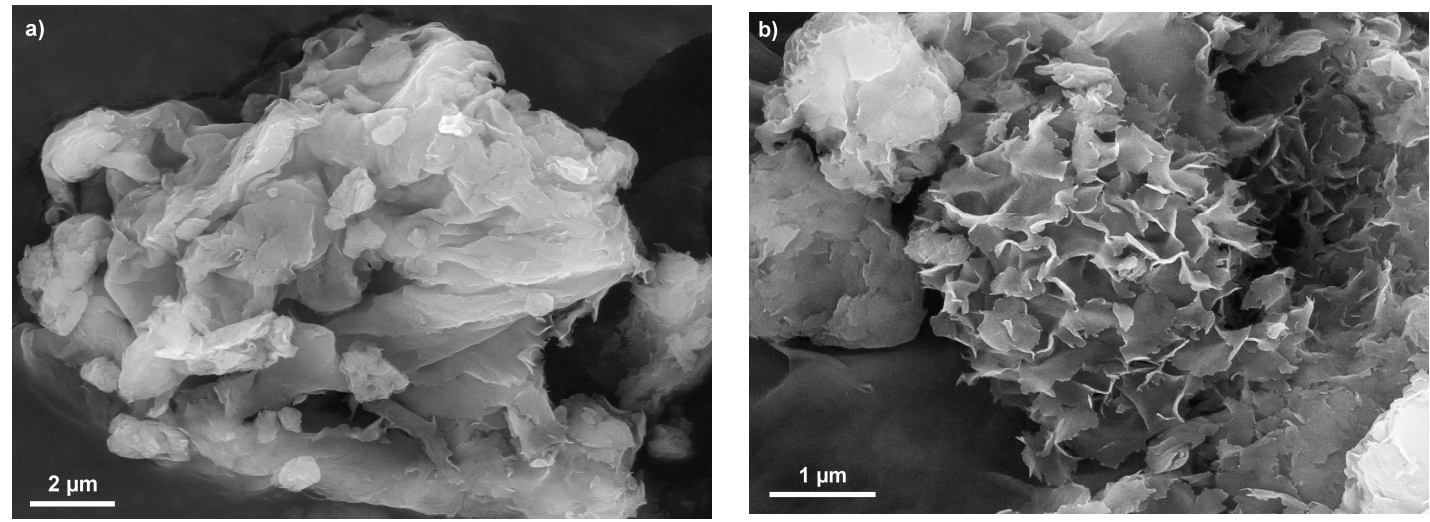

Figure 5. ESEM images (a) distribution of micro aggregates in the raw material; and (b) typical fluffy smectite morphology of the particles in the clay fraction.

The layer charge had to be derived from the structural formula because layer charge measurements based on Lagaly [45] were not possible, owing to very broad peaks of low intensities in XRD patterns of n-alkylammonium exchanged samples. The specific surface area $\left(A_{S}\right)$ of the raw material and the clay fraction is $278 \mathrm{~m}^{2} / \mathrm{g}$ and $283 \mathrm{~m}^{2} / \mathrm{g}$, respectively. The As revealed three layers per stack $(n=3)$ and a very small lateral layer dimension between 60 and $80 \mathrm{~nm}$.

\subsection{Interstratification Studies}

First, a turbostratic talc/smectite interstratification was modelled. The best result was reached using the following parameter ( $($ Reichweite $=0, \mathrm{~d}(001)$ for turbostratic talc $=0.96 \mathrm{~nm}$, smectite content $=0.7$, Low $=1 ;$ HighN $=5 ; \delta=2$ ). Not all features in the XRD pattern could be reproduced with a turbostratic talc/smectite interstratification (Figure 6a). Therefore, a turbostratic talc pattern (Figure 6b) was modelled, too. The parameter LowN, HighN, and $\delta$ were the same as already chosen for the interstratification. The $\mathrm{d}(001)$ for the turbostratic talc was fixed to $0.96 \mathrm{~nm}$. The two modelled patterns (Figure $6 \mathrm{~b}$ ) were mixed in the ratio: $75 \%$ turbostratic talc/smectite interstratification and $25 \%$ turbostratic talc. Figure $6 c, d$ shows that all features could now be reproduced. The masked range (Figure $6 a-d)$ of the pattern was excluded, because in this region the $\mathrm{d}(02,11)$ reflection of trioctahedral clay minerals is located [9]. The occurrence of this reflection indicated that the particles were not completely oriented 
parallel to the sample holder. The variation of the Fe content from 0 to 0.1 has no significant influence in the patterns, therefore the iron content in the smectite component was fixed to 0.05 p.f.u. according to the chemical composition (Table 1). HighN and $\delta$ were very low to reproduce the broad diffraction peaks. Higher values would produce very sharp diffraction peak profiles. The low values agreed with the results of BET measurements.

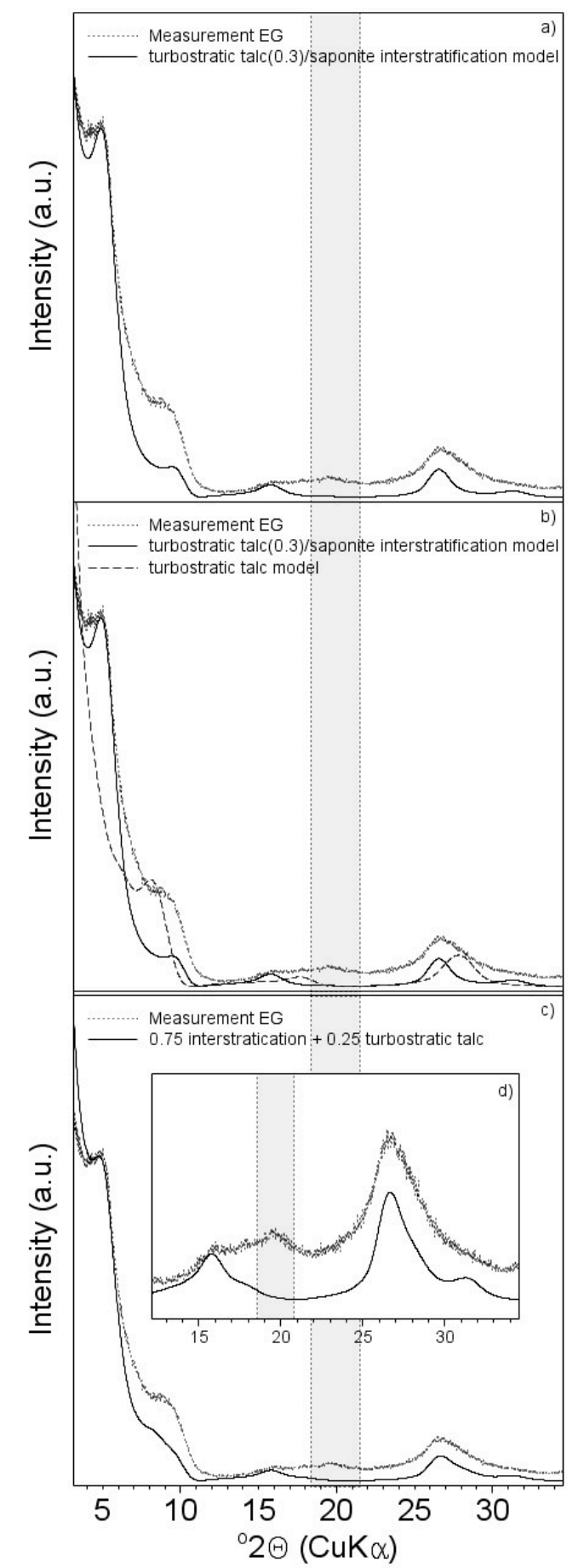

Figure 6. EG-treated XRD pattern of the oriented clay fraction sample in comparison to the modeled pattern by NEWMOD: (a) turbostratic talc (0.3)/saponite interstratification model; (b) turbostratic talc(0.3)/saponite interstratification model + turbostratic talc model; (c) mixture of interstratification (0.75) model + turbostratic talc model; and (d) enlarged view of (c). 
According to the modeling results, the structural formula of the smectite in the interstratification was calculated [46] using the chemical analysis of the clay fraction (Table 1). Based on Cuadros et al. [10], we assumed that the chemical variability of turbostratic talc and talc is low compared to smectite. Thus, we applied the ideal talc formula $\left(\mathrm{Si}_{4.0}\right)\left(\mathrm{Mg}_{3.0}\right) \mathrm{O}_{10}(\mathrm{OH})_{2}$ for both talc components. The structural formula for smectite (70\%) was then calculated as: $\mathrm{M}_{0.31}^{+}\left(\mathrm{Si}_{3.77} \mathrm{Al}_{0.23}\right)\left(\mathrm{Mg}_{2.84} \mathrm{Fe}_{0.05} \mathrm{Al}_{0.03}\right) \mathrm{O}_{10}(\mathrm{OH})_{2}$. $\mathrm{M}^{+}$includes the interlayer cations $\mathrm{Na}, \mathrm{Ca}$, and $\mathrm{K}$. The determined structural formula for the smectite component is typical for a saponite type III rather than for stevensite, which was found by Martin de Vidales [3] in similar materials.

The $\mathrm{H}_{2} \mathrm{O}$ release below $300{ }^{\circ} \mathrm{C}$ was higher than expected for a mixture of a Na-rich swelling clay mineral (average $\mathrm{H}_{2} \mathrm{O}$ content at $53 \%$ r.h. at about $12.5 \%$, unpublished data) and a fine-grained non-swelling clay mineral (maximum $\mathrm{H}_{2} \mathrm{O}$ content at $53 \%$ r.h. of $5 \%$ ). The high $\mathrm{H}_{2} \mathrm{O}$ binding ability is caused by the extreme small material grains and large surface area.

To determine the mass loss resulting from dehydroxylation of the clay mineral components the overall mass loss between $600{ }^{\circ} \mathrm{C}$ and $1100{ }^{\circ} \mathrm{C}$ was corrected by the mass loss caused by thermal carbonate decomposition. Even $1 \%$ calcite would result in a mass loss of $0.44 \%$, which would cause an overestimation of $\mathrm{OH}$ from overall mass loss in TG above $600{ }^{\circ} \mathrm{C}$. Talc contains $4.6 \%$ water as hydroxyl groups and saponite $4.66 \%$. The investigated sample consists of $75 \%$ turbostratic talc $(0.3) /$ smectite interstratification and $25 \%$ turbostratic talc. Thus, the amount of turbostratic talc from the interstratification corresponds to $22.5 \%$ of total layers and the sum of turbostratic talc corresponds to $47.5 \%$. The amount of saponite from the interstratification totaled $52.5 \%$ of all layers. The amount of $\mathrm{OH}$ from $47.5 \%$ talc is $2.19 \%$ and from $52.5 \%$ saponite is $2.45 \%(2.19 \%+2.45 \%=4.64 \%)$. The carbonate content in the clay sample fraction was $0.36 \%$, which results in a mass loss of $0.16 \%$. With the carbonate correction, the mass lost owing to dehydroxylation is $4.66 \%$ instead of $4.82 \%$ (uncorrected) and this is equivalent to the theoretical value. This result indicates no additional surface hydroxyl groups. The CEC of the raw material $(37 \mathrm{cmol}(+) / \mathrm{kg})$ is equal to the CEC of the clay fraction $(40 \mathrm{cmol}(+) / \mathrm{kg})$. The calculated layer charge of the pure smectite $\left(0.31\right.$ p.f.u.; $\left.\mathrm{M}_{\text {smectite }}=385.35 \mathrm{~g} / \mathrm{mol}\right)$ revealed a CEC of $80 \mathrm{cmol}(+) / \mathrm{kg}$. Thus, $52.5 \%$ saponite had a CEC of $42 \mathrm{cmol}(+) / \mathrm{kg}$, which equates the measured CEC $(40 \mathrm{cmol}(+) / \mathrm{kg})$ of the clay fraction.

According to Faust \& Murata [47], Veniale and Van der Marel [48], Grimshaw [49], Alietti and Mejsner [1], and Post [50], the endothermic decomposition of pure talc and saponite, as well as talc-saponite interstratifications involves crystallization of enstatite and cristobalite. Decomposition (endothermic) and recrystallization (exothermic) are out of the temperature range (up to $1100{ }^{\circ} \mathrm{C}$ ) of conventional STA measurement systems [1,48-50]. In contrast, the investigated turbostratic talc-saponite interstratification showed an exothermic peak with a maximum at $815{ }^{\circ} \mathrm{C}$ superimposing with the endothermic dehydroxylation of the interstratification. The low temperature of dehydroxylation and decomposition for turbostratic talc-saponite interstratification is again caused by the small particle size.

\subsection{Surface Properties of the Interstratification}

The specific surface area of the raw material is $278 \mathrm{~m}^{2} / \mathrm{g}$ and is only slightly lower than the specific surface area of the clay fraction at $283 \mathrm{~m}^{2} / \mathrm{g}$, and is comparable to engineered adsorption materials (Table 2, [51]).

Table 2. Surface and porosity characteristics of the talc-saponite interstratification in comparison to an acid-modified bentonite based on BET $\left(\mathrm{p} / \mathrm{p}_{0}=0.01-0.2\right)$ and DFT calculations.

\begin{tabular}{cccc}
\hline Parameters & EX M 1694 Bulk & EX M 1694 $<\mathbf{2 ~} \boldsymbol{\mu m}$ & Ca-Saturated Bentonite Acid-Modified \\
\hline $\mathrm{A}_{\mathrm{S}} \mathrm{BET}\left(\mathrm{m}^{2} / \mathrm{g}\right)$ & 278 & 283 & 236 \\
$\mathrm{~A}_{\text {MicroP }}\left(\mathrm{m}^{2} / \mathrm{g}\right)$ & 139 & 140 & 44 \\
$\mathrm{~A}_{\text {MesoP }}\left(\mathrm{m}^{2} / \mathrm{g}\right)$ & 138 & 142 & 189 \\
$\mathrm{~A}_{\text {MacroP }}\left(\mathrm{m}^{2} / \mathrm{g}\right)$ & 1 & 1 & 3 \\
\hline
\end{tabular}


Engineered adsorption materials that are produced by acid treatment of smectitic clays to adjust surface area and porosity [52] generate hazardous waste. The studied material can be used as mined and, in addition, possesses a small amount of macropores, but large numbers of micropores (50\%) and mesopores (50\%). Therefore, it might not only be suitable for further (bio)-separation processes of low molecular substances without pretreatment, but also for adsorption of macromolecules, like proteins and enzymes.

\section{Conclusions}

Sample EX M 1694 from the Madrid basin (Spain) is similar to the pink clay from the same provenance studied by Martin de Vidales [3] and Cuevas et al. [4], but the interstratification consists of $30 \%$ turbostratic talc and $70 \%$ saponite type III rather than turbostratic talc and stevensite (due to tetrahedral and octahedral substitutions). In addition to the interstratification (75\%), the sample contained $25 \%$ turbostratic talc. The fine grained natural material with small lateral layer dimension and low number of layers per stack possesses a large surface area comparable to engineered sorption materials. Therefore, it is highly suitable for application as mined without chemical pretreatment, which reduces the environmental burden. Furthermore, low particle size reduces thermal stability and dehydroxylation, and recrystallization takes place well below $1000^{\circ} \mathrm{C}$. The exceptional suitability of the studied material for absorbents in biotechnology processes, for mycotoxins and pesticides can be explained by its physical and chemical properties.

Acknowledgments: We are grateful to Katherina Rüping and Doreen Rapp for their help in the laboratory. The authors acknowledge Marita Heinle (Karlsruhe Institute of Technology, KIT) for ICP-OES analyses, Utz Kramar (Karlsruhe Institute of Technology, KIT) for XRF analyses and Peter Weidler (Karlsruhe Institute of Technology, KIT) for gas adsorption measurements. We are very grateful to Javier Cuadros, Steve Guggenheim, and two anonymous reviewer for discussions that improved the manuscript.

Author Contributions: Friedrich Ruf, Ulrich Sohling, Rainer Schuhmann, and Katja Emmerich conceived the project and designed the overall experimental strategy. Friedrich Ruf and Ulrich Sohling selected the sample. Annett Steudel performed the XRD, the STA and the CEC experiments and analyzed the data. Annett Steudel performed the modeling of the one-dimensional X-ray pattern. Frank Friedrich performed and evaluated the FTIR and ESEM experiments. All authors participated in writing the manuscript.

Conflicts of Interest: The authors declare no conflict of interest.

\section{References}

1. Alietti, A.; Mejsner, J. Structure of a talc/saponite mixed-layer mineral. Clays Clay Miner. 1980, 28, 388-390. [CrossRef]

2. Eberl, D.D.; Jones, G.; Khoury, H.N. Mixed-layer kerolite/stevensite from the Amargosa Desert, Nevada. Clays Clay Miner. 1982, 57, 115-133. [CrossRef]

3. De Vidales, J.L.M.; Pozo, M.; Alia, J.M.; Garcia-Navarro, F.; Rull, F. Kerolite-stevensite mixed-layers from the Madrid basin, Central Spain. Clay Miner. 1991, 26, 329-342. [CrossRef]

4. Cuevas, J.; Pelayo, M.; Rivas, P.; Leguey, S. Characterization of Mg-clays from the Neogene of the Madrid basin and their potential as backfilling and sealing material in high level radioactive waste disposal. Appl. Clay Sci. 1993, 7, 383-406. [CrossRef]

5. Pozo, M.; Casas, J. Origin of kerolite and associated Mg clays in palustrine-lacustrine environments. The Esquivias deposit (Neogene Madrid Basin, Spain). Clay Miner. 1999, 34, 395-418. [CrossRef]

6. De Santiago Buey, C.; Suarez Barrios, M.; Garcia Romero, E.; Dominiguez Diaz, M.C.; Doval Montoya, M. Electron microscopic study of the illite-smectite transformation in the bentonites from Cerro del Aquila (Toledo, Spain). Clay Miner. 1998, 33, 501-510. [CrossRef]

7. Brindley, G.W.; Bish, D.L.; Wan, H.-M. The nature of kerolite, its relation to talc and stevensite. Mineral. Mag. 1977, 41, 443-452. [CrossRef]

8. Bailey, S.W. Summary of recommendations of AIPEA nomenclature committee on clay minerals. Am. Mineral. 1980, 65, 1-7.

9. Brindley, G.W.; Brown, G. Crystal Structures of Clay Minerals and Their X-ray Identification; Monograph 5; Mineralogical Society: London, UK, 1980; p. 539. 
10. Cuadros, J.; Vesselin, M.D.; Fiore, S. Crystal chemistry of the mixed-layer sequence talc-talc-smectite-smectite from submarine hydrothermal vents. Am. Mineral. 2008, 93, 1338-1348. [CrossRef]

11. Nickel, E.H.; Nichols, M.C. IMA/CNMNC List of Mineral Names. Available online: http://nrmima.nrm.se/ /MINERALlist.pdf (accessed on 22 May 2008).

12. Guggenheim, S. Introduction to Mg-rich clay minerals: Structure and composition. In Magnesian Clays: Characterization, Origin and Applications; Pozo, M., Galan, E., Eds.; AIPEA Educational Series: Bari, Italy, 2015; pp. 1-62.

13. Perdikatsis, B.; Burzlaff, H. Strukturverfeinerung am Talk $\mathrm{Mg}_{3}\left[(\mathrm{OH})_{2} \mathrm{Si}_{4} \mathrm{O}_{10}\right]$. Z. Kristallogr. 1981, 156, 177-186. [CrossRef]

14. Guggenheim, S.; Adams, J.M.; Bain, D.C.; Bergaya, F.; Brigatti, M.F.; Drits, V.A.; Formoso, M.L.L.; Galán, E.; Kogure, T.; Stanjek, H. Summary of recommendations of nomenclature committees relevant to clay mineralogy: Report of the association Internationale pour l'etude des argiles (aipea) nomenclature committee for 2006. Clays Clay Miner. 2006, 54, 761-772. [CrossRef]

15. Newman, A.C.D. Chemistry of Clays and Clay Minerals; Monograph 6; Mineralogical Society: London, UK, 1987; p. 480.

16. Köster, H.M.; Schwertmann, U. Beschreibung einzelner Tonminerale. In Tonminerale und Tone: Struktur, Eigenschaften, Anwendung und Einsatz in Industrie und Umwelt; Jasmund, K., Lagaly, G., Eds.; Steinkopff Verlag: Darmstadt, Germany, 1993; pp. 33-88.

17. Mackenzie, R.C. Saponite from Allt Ribhein, Fiskavaig Bay, Skye. Mineral. Mag. 1957, 31, 672-680. [CrossRef]

18. Moore, D.M.; Reynolds, R.C., Jr. X-ray Diffraction and the Identification and Analysis of Clay Minerals; Oxford University Press: New York, NY, USA, 1997; p. 378.

19. Ferrage, E.; Sakharov, B.A.; Michot, L.J.; Lanson, B.; Delville, A.; Cuello, G.J. Water organization in Na-saponite: An experimental validation of numerical data. Geochim. Cosmochim. Acta 2010, 74, A289.

20. Ferrage, E.; Lanson, B.; Sakharov, B.A.; Geoffroy, N.; Jacquot, E.; Drits, V.A. Investigation of dioctahedral smectite hydration properties by modeling of X-ray diffraction profiles: Influence of layer charge and charge location. Am. Mineral. 2007, 92, 1731-1743. [CrossRef]

21. Temme, H.; Sohling, U.; Suck, K.; Ruf, F.; Niemeyer, B. Separation of aromatic alcohols and aromatic ketones by selective adsorption on kerolite-stevensite clay. Colloids Surf. A 2011, 377, 290-296. [CrossRef]

22. Sohling, U.; Haimerl, A. Use of Stevensite for Mycotoxin Adsorption. Patent WO 2006119967, 17 July 2012.

23. Ureña-Amate, M.D.; Socías-Viciana, M.; González-Pradas, E.; Saifi, M. Effects of ionic strength and temperature on adsorption of atrazine by a heat treated kerolite. Chemosphere 2005, 59, 69-74. [CrossRef] [PubMed]

24. Sohling, U.; Ruf, F. Stevensite and/or Kerolite Containing Adsorbents for Binding Interfering Substances during the Manufacture of Paper. Patent WO 200702941, 1 March 2007.

25. Wolters, F.; Lagaly, G.; Kahr, G.; Nüesch, R.; Emmerich, K. A comprehensive characterization of dioctahedral smectites. Clays Clay Miner. 2009, 57, 115-133. [CrossRef]

26. Steudel, A.; Batenburg, L.; Fischer, H.; Weidler, P.G.; Emmerich, K. Alteration of swellable clays by acid treatment. Appl. Clay Sci. 2009, 44, 105-115. [CrossRef]

27. Tributh, H.; Lagaly, G. Aufbereitung und Identifizierung von Boden- und Lagerstättentonen Teil I: Aufbereitung der Proben im Labor. GIT Fachzeitschrift für das Laboratorium 1986, 30, 524-529.

28. Whitney, D.L.; Evans, B.W. Abbreviations for names of rock-forming minerals. Am. Mineral. 2010, 95, 185-187. [CrossRef]

29. NEWMOD for Windows ${ }^{T M}$ : The Calculation of One-Dimensional X-ray Diffraction Patterns of Mixed-Layered Clay Minerals; Reynolds, R.C., Jr. and Reynolds, R.C., III.: Hanover, NH, USA, 1996; p. 25.

30. Emmerich, K. Thermal analysis in the characterization and processing of industrial minerals. In Advances in the Characterization of Industrial Minerals; EMU, Notes in Mineralogy: London, UK, 2011; pp. 129-170.

31. Meier, L.P.; Kahr, G. Determination of the cation exchange capacity (CEC) of clay minerals using the complexes of copper(II) ion with triethylenetetramine and tetraethylenepentamine. Clays Clay Miner. 1999, 47, 386-388. [CrossRef]

32. Brunauer, S.; Emmett, P.H.; Teller, E. Adsorption of gases in multimolecular layers. J. Am. Chem. Soc. 1938, 60, 309-319. [CrossRef] 
33. Sing, K.S.W.; Everett, D.H.; Haul, R.A.W.; Moscou, L.; Pierotti, R.A.; Rouquerol, J.; Siemieniewska, T. Reporting physisorption data for gas/solid systems with special reference to the determination of surface area and porosity. Pure Appl. Chem. 1985, 57, 603-619. [CrossRef]

34. Lowell, S.; Shields, J.E.; Thomas, M.A.; Thommes, M. Characterization of porous solids and powders. In Surface Area, Pore Size and Density; Springer: Berlin, Germany, 2006; p. 347.

35. White, G.N.; Zelazny, L.W. Analysis and implications of the edge structure of dioctahedral phyllosilicates. Clays Clay Miner. 1988, 36, 141-146. [CrossRef]

36. Tournassat, C.; Neaman, A.; Villiéras, F.; Bosbach, D.; Charlet, L. Nanomorphology of montmorillonite particles: Estimation of the clay edge sorption site density by low-pressure gas adsorption and AFM observations. Am. Miner. 2003, 88, 1989-1995. [CrossRef]

37. Delavernhe, L.; Steudel, A.; Darbha, G.K.; Schäfer, T.; Schuhmann, R.; Wöll, C.; Geckeis, H.; Emmerich, K. Influence of mineralogical and morphological properties on the cation exchange behavior of dioctahedral smectites. Colloids Surf. A 2015, 481, 591-599. [CrossRef]

38. Russel, J.D.; Fraser, A.R. Infrared methods. In Clay Mineralogy: Spectroscopic and Chemical Determinative Methods; Wilson, M.J., Ed.; Chapman \& Hall: London, UK, 1994; pp. 11-67.

39. Farmer, V.C. The Infrared Spectra of Minerals; Monograph 4; Mineralogical Society: London, UK, $1974 ;$ p. 331.

40. Gates, W.P. Infrared Spectroscopy and the Chemistry of Dioctahedral Smectites. In The Application of Vibrational Spectroscopy to Clay Minerals and Layered Double Hydroxides; Workshop Lectures; Kloprogge, J.T., Ed.; The Clay Mineral Society: Boulder, CO, USA, 2005; Volume 13, pp. 125-168.

41. Cuadros, J.; Altaner, S.P. Compositional and structural features of the octahedral sheet in mixed-layer illite/smectite from bentonites. Eur. J. Miner. 1988, 10, 111-124.

42. Farmer, V.C. The infra-red spectra of talc, saponite, and hectorite. Mineral. Mag. 1958, 31, 829-844. [CrossRef]

43. Kloprogge, J.T.; Frost, R.L. The effect of synthesis temperature on the FT-Raman and FT-IR spectra of saponites. Vib. Spectrosc. 2000, 23, 119-127. [CrossRef]

44. Van der Marel, H.W.; Beutelspacher, H. Atlas of Infrared Spectroscopy of Clay Minerals and Their Admixtures; Elsevier: Amsterdam, The Netherlands, 1976; p. 191.

45. Lagaly, G. Layer Charge Determination by Alkylammonium Ions. In Layer Charge Characteristics of 2:1 Silicate Clay Minerals; Mermut, A.R., Ed.; The Clay Minerals Society: Aurora, CO, USA, 1994; Volume 6, pp. 1-46.

46. Stevens, R.E. A system for calculating analyses of micas and related minerals to end members. US Geol. Surv. Bull. 1945, 950, 101-119.

47. Faust, G.T.; Murata, K.J. Stevensite, redefined as a member of the montmorillonite group. Am. Mineral. 1953, 38, 973-978.

48. Veniale, F.; Van der Marel, H.W. A regular Talc-Saponite mixed layer mineral from Ferriere, Nure Valley (Piacenza Province, Italy). Contrib. Mineral. Petrol. 1968, 17, 237-254. [CrossRef]

49. Grimshaw, R.W. The Chemistry and Physics of Clays and Allied Ceramic Materials, 4th ed.; Ernest Benn Limited: London, UK, 1971; p. 1024.

50. Post, J.L. Saponite from Near Ballarat, California. Clays Clay Miner. 1984, 32, 147-153. [CrossRef]

51. Sohling, U.; Ruf, F.; Schurz, K.; Emmerich, K.; Steudel, A.; Schuhmann, R.; Weidler, P.G.; Ralla, K.; Riechers, D.; Kasper, C.; et al. Natural mixture of silica and smectite as a new clayey material for industrial applications. Clay Miner. 2009, 44, 525-537. [CrossRef]

52. Komadel, P.; Madejová, J. Acid activation of clay minerals. In Handbook of Clay Science, 2nd ed.; Bergaya, F., Theng, B.K.G., Lagaly, G., Eds.; Elsevier: Amsterdam, The Netherlands, 2006; pp. 263-287.

(C) 2017 by the authors; licensee MDPI, Basel, Switzerland. This article is an open access article distributed under the terms and conditions of the Creative Commons Attribution (CC-BY) license (http://creativecommons.org/licenses/by/4.0/). 